\title{
Application of Bacterial Cellulose (BC) in Natural Facial Scrub
}

\author{
Norhasliza Hasan, Dayang Radiah Awang Biak, Suryani Kamarudin \\ Department of Chemical and Environmental Engineering, Faculty of Engineering \\ Universiti Putra Malaysia, Serdang, 43400, Selangor, Malaysia \\ E-mail:norhaslizahasan@ymail.com,dayang@eng.upm.edu.my,suryani@eng.upm.edu.my
}

\begin{abstract}
A new facial scrub containing only natural ingredients and powdered bacterial cellulose (BC) was formulated. The other ingredients used in the formulation include powdered glutinous rice, aloe vera extract, ascorbic acid (Vitamin C) powder and olive oil. The rheological behaviours of the formulated and commercial facial scrubs were tested using plate and plate rheometer. Both formulated and commercial facial scrubs shows shear thinning behaviour (non-Newtonian liquid). The formulated facial scrub

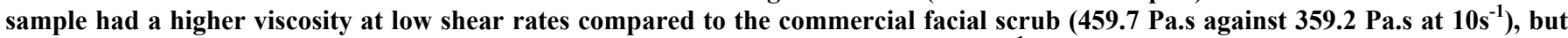
had a nearly similar viscosity at high shear rates (197.2 Pa.s against 192 Pa.s at $25 \mathrm{~s}^{-1}$ ). By adding preservative, the shelf life of the scrub was two times longer than that without preservatives. The tested sample dried out after 10 minutes at room temperature $\left(\sim 30^{\circ} \mathrm{C}\right)$.
\end{abstract}

Keywords - Acetobacter xylinum, bacterial cellulose, facial scrub, traditional cosmetic.

\section{INTRODUCTION}

Cosmetics are substances that are used to enhance the appearance of human body including the eyes, hair, face and nail [1]. Cosmetic is defined as a product that is applied to the human body for cleansing, beautifying, promoting attractiveness or altering the appearance without affecting the body structure or functions (United States Food and Drug Administration [USFDA], 2004). Nowadays, most cosmetics are used by consumers to enhance their beauty without considering the effects when they are applied to the skin. One of the effects is skin allergy cause by the usage of paraben [2]. Thus, natural skin care products are mostly recommended to be used to prevent harm to the consumer.

Natural skin care defined by classic definition is the skin care product that totally utilizes botanic or naturally-derived ingredients such as herbs, roots, essential oils and flowers. No synthetic chemicals were used or combined with other ingredients that are present in these products [3].

To control microbial growth and to stabilize the cosmetic product, some form of preservatives need to be used. The amount of preservatives used depends on the microbial and stability tests. Ascorbic acid (vitamin C), extracted from citrus fruits such as orange, could inhibit fungus activity and is typically used in cosmetic industry as preservative [4].

A lot of industries utilize non-Newtonian fluids, gels or emulsions in their products. At present time, non-newtonian polymers uses a lot in industries such as food, textile, pharmaceutical, cosmetics, etc. The behavior of the liquid phase could be affected by the presence of small quantities of polymers. One of the most important characteristics is the influence of shear rate on the fluid viscosity.

Nowadays, bacterial cellulose has been widely use in paper making, food, pharmaceutical and also in cosmetic industry. Previous study claimed that the usage of cellulose fibrils in cosmetic uses to produce stable oil in water emulsion without additional of surfactant, has the advantage of not irritant to skin [5]. One of the earliest inventions that previously used cellulose powder is in powdery cosmetic, that resulting in excellent spreadability and adhesion either in a loose state or a pressed state [6]. A recent discovery of bacterial cellulose in cosmetic found that the assembly of bacterial cellulose with other powdered cosmetic composition [7].

However, no attempt has been made to study rheological behavior of the facial scrub by the addition of bacterial cellulose. In particular, little information is available on the effect of bacterial cellulose in the cosmetic industry. The additional of bacterial cellulose in cosmetic composition may provide valuable information on the role of bacterial cellulose in cosmecuetical area.

The aims of this work were to determine the rheological behaviors of the formulated facial scrub and to study the spreadability and drying time of the facial scrub combine with the shelf life assessment. 


\section{MATERIALS AND METHODS}

\section{A. Organism and media}

Cell suspension culture of Acetobacter xylinum was purchased from Malaysian Agricultural Research and Development Institute (MARDI), Serdang, Selangor, Malaysia. To produce bacterial cellulose, the modified Schramm Hestrin medium was prepared [8]. Approximately $2 \%(\mathrm{w} / \mathrm{v})$ carbon source, $0.5 \%(\mathrm{w} / \mathrm{v})$ yeast extract, $0.5 \%$ (w/v) bactopeptone, $0.27 \%(\mathrm{w} / \mathrm{v}) \mathrm{Na}_{2} \mathrm{HPO}_{4}$ and $0.115 \%(\mathrm{w} / \mathrm{v})$ citric acid. However, here, date extract was used as carbon source.

\section{B. Cultivation}

To prepare the media culture, fresh dates flesh were weighed and mixed with deionized water with ratio of 1:10. The mixture was sonicated for 30 minutes and later filtered to obtain dates extract. Then, the collected extract was mixed with other nutrients to form the media; the $\mathrm{pH}$ was set at 6.0. The sterilization process was done for $15 \mathrm{~min}$ at $121^{\circ} \mathrm{C}$. The sample was inoculated for 10 days before harvested.
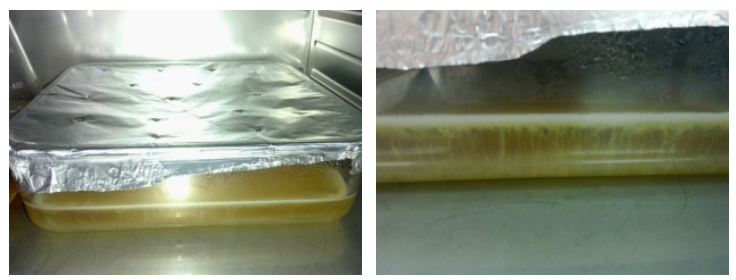

Fig. 1 Fermentation of bacterial cellulose

\section{Preparation of cellulose powder}

The cellulose layer was harvested after 10 days of fermentation. The purification process was conducted as that described by previous research [9]. To prepare cellulose powder, dry cellulose sheet was ground using laboratory blender and mill. The fine powder produced was used as it is in the formulation.

\section{Facial scrub formulation}

Other ingredients that were mixed with the cellulose powder to form the facial scrub were powdered glutinous rice (size $\sim 400 \mu \mathrm{m}$ ), ascorbic acid powder, aloe vera extract and olive oil.

TABLE 1

THE INGREDIENTS FOR FACIAL SCRUB

\begin{tabular}{|l|l|}
\hline \multicolumn{1}{|c|}{ Ingredient } & \multicolumn{1}{|c|}{$\begin{array}{c}\text { Weight or } \\
\text { Volume }\end{array}$} \\
\hline Cellulose powder & $1 \mathrm{~g}$ \\
\hline Glutinous rice powder & $2 \mathrm{~g}$ \\
\hline Ascorbic acid powder & $6 \mathrm{~g}$ \\
\hline Aloe vera extract & $6 \mathrm{ml}$ \\
\hline Olive oil & $2 \mathrm{ml}$ \\
\hline
\end{tabular}

\section{E. Rheological studies}

The rheological behaviour of the formulation was performed using HAAKE RheoWin plate and plate rheometer. The gap size for the plates was set at $0.1 \mathrm{~mm}$. Both samples, formulated and commercial facial scrubs were sheared at $25^{\circ} \mathrm{C}$. The relationship between shear stress and shear strain of the sample was studied.

\section{F. Shelf life assessment}

Two formulation samples were prepared with and without the presence of additional of preservative. The amount added is as shown in Table 2. Both samples were left at room temperature $\left(\sim 30^{\circ} \mathrm{C}\right)$, in sealed plastic petri dish. Observation was conducted daily until the first appearance of fungus in both samples.

TABLE 2

COMPARISON BETWEEN DIFFERENT FACIAL SCRUBS FOR SHELF LIFE TEST

\begin{tabular}{|l|l|l|l|}
\hline $\begin{array}{c}\text { Sample A: } \\
\text { With Preservative }\end{array}$ & $\begin{array}{c}\text { Weight } \\
\text { or } \\
\text { Volume }\end{array}$ & $\begin{array}{c}\text { Sample B: } \\
\text { Without } \\
\text { Preservative }\end{array}$ & $\begin{array}{c}\text { Weight } \\
\text { or } \\
\text { Volume }\end{array}$ \\
\hline Cellulose powder & $1 \mathrm{~g}$ & Cellulose powder & $1 \mathrm{~g}$ \\
\hline $\begin{array}{l}\text { Glutinous rice } \\
\text { powder }\end{array}$ & $2 \mathrm{~g}$ & $\begin{array}{l}\text { Glutinous rice } \\
\text { powder }\end{array}$ & $2 \mathrm{~g}$ \\
\hline $\begin{array}{l}\text { Ascorbic acid } \\
\text { powder }\end{array}$ & $6 \mathrm{~g}$ & Aloe vera extract & $6 \mathrm{ml}$ \\
\hline Aloe vera extract & $6 \mathrm{ml}$ & Olive oil & $2 \mathrm{ml}$ \\
\hline Olive oil & $2 \mathrm{ml}$ & & \\
\hline
\end{tabular}

\section{G. Spreadability and drying time}

To study the spreadability of the sample, approximately $1 \mathrm{~g}$ of sample was spread on the prepared grid $(7 \times 20 \times 20) \mathrm{mm}$ with $\sim 1.31 \mathrm{~mm}$ of average sample thickness and timer was set to let them dried at the room temperature $\left(\sim 30^{\circ} \mathrm{C}\right)$. The sample considered as dried when all particles of sample could remove easily from the grid and the sample was weighted by three readings to get constant weight.

\section{RESULTS AND DISCUSSION}

\section{A. Rheological studies for facial scrub formulation}

Fig. 2 shows the relationship between the kinematic viscosity of the formulation with the shear rate applied. Here, a commercially available scrub containing particles were tested and compared with the formulated facial scrub.

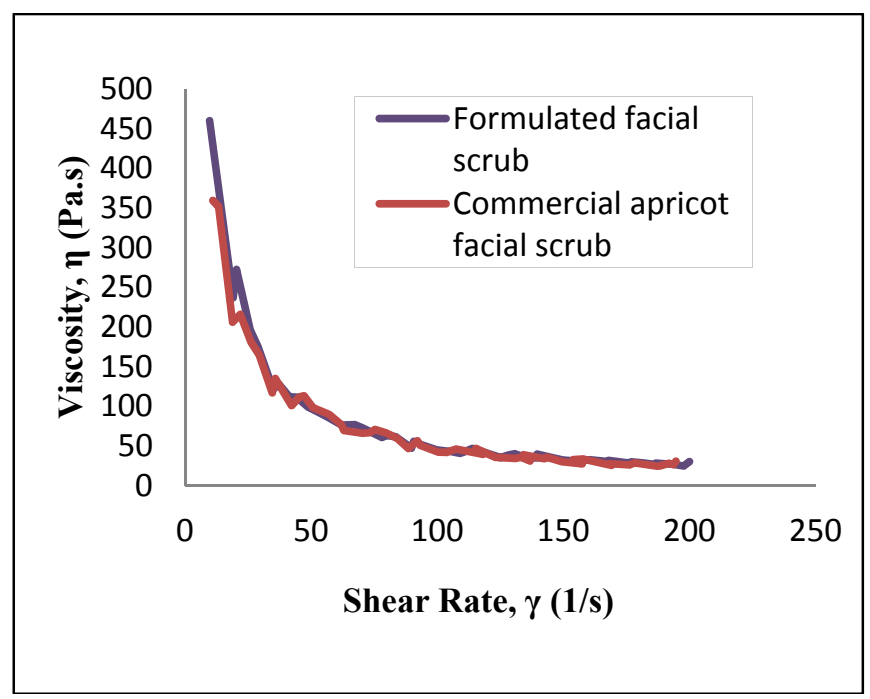

Fig. 2 Viscosity curve for a) formulated facial scrub and b) commercial apricot facial scrub 
From Fig. 2, it can be observed that the facial scrub showed similar kinematic viscosity trend to commercial facial scrub when sheared at $25^{\circ} \mathrm{C}$. As expected, the kinematic viscosity $(\eta)$ of the pastes decreases with increasing shear rates. Both formulations show shear thinning behaviour when subjected to shear at $25^{\circ} \mathrm{C}$.

The formulated facial scrub sample had a higher viscosity at low shear rates compared to the commercial facial scrub (459.7 Pa.s against 359.2 Pa.s at $10 \mathrm{~s}^{-1}$ ), but had a nearly similar viscosity at high shear rates (197.2 Pa.s against 192 Pa.s at $25 \mathrm{~s}^{-1}$ ). This significant difference is likely due to conformational differences between the two mixtures. When the biopolymer (cellulose) chains are sheared, they unwind and align in the direction of shear, so as a measure of flow resistance, the viscosity decreased. The greater the decrease in the viscosity of the sample, the more intense a scrubbing effect can be.

\section{B. Shelf life assessment of the facial scrub}
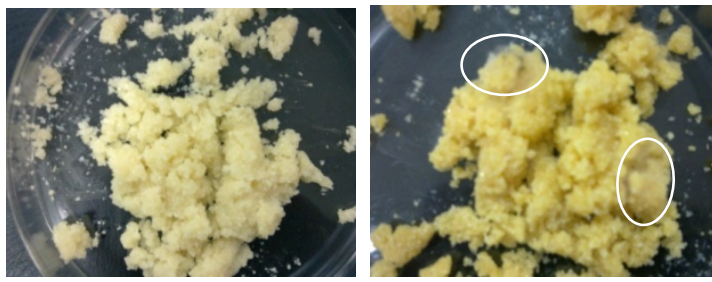

Fig. 3 a) Sample A at day 0 and b) Sample A at day 9
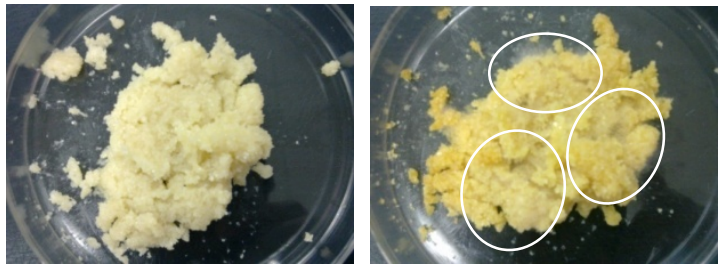

Fig. 4 a) Sample B at day 0 and b) Sample B at day 6

The shelf life of cosmetics depends on the content of preservatives added in the mixture. The amount and type of preservative used is determined by other criteria such as composition of the preparation [10]. Different preservatives with specific amount, will give different shelf life results to the mixture depending on the surrounding temperature and humidity. In this experiment, ascorbic acid (vitamin C) was used as preservative. Samples were prepared as described previously. The assessment was conducted based on the presence of fungus on the mixture. The snapshot photos of both formulations are shown in Fig. 3 and 4.

The results show that when samples $\mathrm{A}$ and $\mathrm{B}$ were left at room temperature $\left(\sim 30^{\circ} \mathrm{C}\right)$, in sealed plastic petri dish, fungus presence can be observed. However, fungus appeared much earlier in Sample B (after 6 days) compared to in Sample A (9 days). It has to be noted that even though Sample A contains preservatives, the fungus still grew, but in a small portion. This could be due to the insufficient amount of ascorbic acid added to the formulated volume.

\section{Spreadability and drying time}

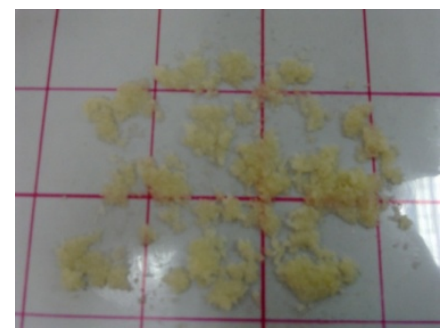

Fig. 5 Grid for spreadability and dryness

Spreadability or also known as slip, is used to identify the glideability of the product across the skin. A facial scrub requires a degree of slip to prevent putting a dry skin under insufficient stress application [11]. Spreading can either occur spontaneously or not; this depends on the surface free energy.

For the tested sample, there was no spreading capability, unless the force was given by scrubbing method in which water has to be added to assist the rubbing effect. To test, the ratio of water $(\mathrm{ml})$ added to weight of sample $(\mathrm{g})$ is $1: 1$. The higher surface tension between sample and skin made the sample stick to the skin during the rubbing process; this can be an undesirable effect.

The result showed that sample dried on the grid within 10 minutes. So, it was sufficient enough for the consumer to apply that facial scrub, because in addition with scrubbing techniques, drying time of the sample will decrease.

\section{CONCLUSIONS}

From the results obtained in this experiment, it ccan be concluded that the new formulated facial scrub that bacterial cellulose as main ingredient has the potentials as utilized future natural facial scrub. This is attributed by the similar viscosity profile as that of commercial facial scrub as well as the natural ingredients used which made it safe on skin.

\section{ACKNOWLEDGMENT}

The authors wish to thank Department of Chemical and Environmental Engineering, Faculty of Engineering, Universiti Putra Malaysia, for technical and facilities supports.

\section{REFERENCES}

[1] F. Aldo, Natural Beauty: A Step by Step Guide to Making Creams, Balms, Tonics and Oil. London: Ebury Press London, 1990.

[2] J.E. Nagel, J.T. Fuscaldo, and P. Fireman, "Paraben allergy," JAMA, pp. 1594-1598, Apr. 1977.

[3] K. A. Walters, and M. S. Roberts, Dermatologic, Cosmeceutic and Cosmetic Development: Theraputic and Novel Approaches. New York: Informa Healthcare USA Inc, 2008.

[4] T. Aburjai, and F. M. Natsheh, "Plants Used in Cosmetics," Phytotherapy Research, pp. 987-1000, 2003.

[5] F. Tournilhac, and R. Lorant, "Composition in the form of an oil-inwater emulsion containing cellulose fibrils, and its uses, especially cosmetic uses," U.S. Patent 6534071, Mar. 18, 2003.

[6] H. Kurisaki, and M. Nishikawa, "powdery cosmetic containing cellulose powder impregnated with moisturizing polymer," U.S. Patent 5024831, jun. 18, 1991.

[7] J.Y. Legendre, "Assembly comprising a substrate comprising biocellulose, and a powdered cosmetic composition to be brought 
into contact with the substrate," U.S. Patent 2009/0041815, Feb. 12, 2009.

[8] S. Yamanaka, K. Watanabe, N. Kitamura, M. Iguchi, S. Mitsuhashi, Y. Nishi, and M. Uryu, "The structure and mechanical properties of sheets prepared from bacterial cellulose," Journal of Material Science, pp. 3141-3145, 1989.

[9] S. Lotfiman, "Production of bacterial cellulose by Acetobacter xylinum using date syrup extracted enriched medium," M. Sc. Thesis, Universiti Putra Malaysia, Serdang, Malaysia, 2011.
[10] U. Wilfried, Cosmetics and Toiletries: Development, Production and Use, ser. Applied Science and Industrial Technology. England: Ellies Horwood, 1991.

[11] M. Bagajewicz, S. Hill, A. Robben, H. Lopez, M. Sanders, E. Sposato, C. Baade, S. Manora, and J. H. Coradin, "Product Design in Price-Competitive Markets: A Case Study of a Skin Moisturizing Lotion," Wiley Online Library, pp. 160-176, 2010. 